\title{
Pengaruh Kecepatan Putar, Gaya Gesek dan Waktu Gesek Terhadap Struktur Mikro dan Laju Korosi Hasil Pengelasan Proses Las Gesek Material Berbeda Baja SUH 3 dan SUH 35
}

\author{
Ali Sai'in ${ }^{1 *}$, Mochamad Muzaki ${ }^{2}$ \\ ${ }^{1}$ Teknik Mesin, Politeknik Negeri Semarang \\ Jl. Prof. H. Soedarto S.H., Tembalang, Semarang \\ ${ }^{2}$ Teknik Mesin, Politeknik Negeri Malang \\ Jl. Soekarno Hatta No. 9 Malang \\ *E-mail: ali.saiin@polines.ac.id
}

\begin{abstract}
Abstrak
Received: 27-02-2020; Accepted: 16-04-2020; Published online: 23-04-2020

Las gesek merupakan salah satu teknologi pengelasan yang digunakan untuk menyambung dua material tanpa menggunakan bahan pengisi. Penyambungan benda kerja dilakukan dengan memanfaatkan gesekan dan tekanan. Pengaturan parameter proses dalam las gesek ini seperti kecepatan putar, gaya gesek, waktu gesek, gaya tempa dan waktu tempa sangat menentukan keberhasilan proses pengelasan. Penelitian dilakukan untuk mengamati pengaruh parameter proses, diantaranya kecepatan putar, gaya gesek, dan waktu gesek terhadap struktur mikro dan laju korosi pada material yang dilas dengan menggunakan las gesek. Material yang digunakan merupakan material yang mempunyai komposisi kimia yang berbeda, yaitu baja SUH 3 dan SUH 35. Pengelasan dilakukan dengan mesin las gesek tipe FW10NC. Pengamatan struktur mikro dilakukan menggunakan mikroskop optik dan SEM (Scanning Electron Microscope)-EDX. Pengujian laju korosi dilakukan dengan alat uji laju korosi sel tiga elektroda dengan bantuan software NOVA 1.8. Hasil penelitian menunjukkan bahwa pada proses pengelasan baja SUH 3 dan SUH 35 terjadi perubahan struktur mikro dan perubahan komposisi kimia pada daerah sambungan. Persentase Cr pada kecepatan putar 2500 rpm sebesar 14.99\% sedangkan pada kecepatan putar 4500 menjadi sebesar 15.82\%. Perubahan parameter proses dapat mengubah laju korosi pada sambungan.
\end{abstract}

Kata kunci: las gesek; laju korosi; struktur mikro.

\begin{abstract}
Friction welding is one of welding technology that used to join two materials without metal filler. Friction and pressure was utilized to join the material. Parameters setting of friction welding process like rotation speed, friction force, friction time, forging force and forging time are determining the successful rate of friction welding process. The aim of this study is to observe the effect of turning speed, friction force, and friction time against microstructure and corrotion rate on weld metal under friction welding process. The material used in this study is a material that has a different chemical composition, which is SUH 3 and SUH 35. Welding process was done with friction welding machine FW10NC type. Micro vickers tester was used to microstructure observation using optical microscope and scaning electron microscope (SEM)-EDX, corrotion rate analyzed with three-electrode cell test equipment with NOVA 1.8 software. The result of this study shown that there were micro structure and chemical composition change at weld metal during welding process SUH 3 and SUH 35 Steel. Cr percentage is $14.99 \%$ at 2500 rpm while increases to $15.82 \%$ at $4500 \mathrm{rpm}$. Change of process parameter can change corrotion rate.
\end{abstract}

Keywords: corrotion rate; friction welding; microstructure.

\section{Pendahuluan}

Seiring perkembangan industri manufaktur, teknologi pengelasan juga mengalami perkembangan sangat baik. Teknologi tersebut berkembang karena tuntutan dari industri-industri yang mengunakan las sebagai metode untuk menyambung logam.

Berdasarkan pada cara terjadinya penyambungan pada pengelasan, proses pengelasan dibagi menjadi dua metode, pengelasan fusi dan pengelasan kondisi padat [1]. Pengelasan fusi adalah proses penggabungan material yang menggunakan peleburan dari sebagian material induk untuk membuat sambungan las. Pengelasan dalam kondisi fusi yang banyak dikenal adalah Shielded metal arc welding (SMAW), tungsten insert gas (TIG), metal insert gas (MIG) dan las oksiasitelin. Sedangkan pengelasan kondisi padat adalah proses penyambungan material dengan temperatur di bawah titik lebur material. Salah satu jenis pengelasan kondisi padat yang paling sering digunakan hingga saat ini adalah friction 
welding atau las gesek. Las gesek merupakan salah satu teknologi pengelasan yang digunakan untuk menyambung dua material tanpa peleburan material. Proses pengelasan dilakukan dengan memanfaatkan gesekan untuk menghasilkan panas dan tekanan untuk menghasilkan penyambungan.

Aplikasi penyambungan dengan menggunakan las gesek seringkali digunakan pada penyambungan material yang berbentuk silinder dan mempunyai diameter kecil. Las gesek umumnya digunakan dalam industri mobil, untuk menyambung as, komponen bak persneling, kolom kemudi dan penyambungan material engine valve. Metode las gesek ini akan lebih mudah untuk menyambung material yang sulit dilas dengan proses las busur, dimana pada proses las busur panas yang dihasilkan tidak merata pada seluruh permukaan material sehingga sambungan yang dihasilkan kurang baik dari segi kekuatan mekanik hasil lasan.

Hingga saat ini para peneliti telah melakukan penelitian tentang las gesek untuk memahami proses las gesek dengan lebih baik lagi. Salah satu penelitian yang telah dilakukan untuk mempelajari lebih jauh tentang las gesek ini adalah penelitian yang dilakukan Kirik dkk. [2]. Variabel proses yang divariasikan dalam penelitian ini adalah putaran spindle, gaya gesek, waktu gesek dan gaya upset, dengan pengamatan terhadap respon kekuatan tarik, kekerasan dan struktur mikro. Penelitian ini menghasilkan informasi bahwa kekuatan tarik paling tinggi terjadi pada daerah di dekat material induk AISI 1040, pada putaran 1700 rpm dengan tekanan 50 MPa, dan waktu 4 detik. Nilai kekerasan tertinggi ditemukan pada daerah sambungan. Pada pengamatan struktur mikro terjadi penurunan ukuran butiran di daerah deformation zone (DZ) pada kedua material.

Penelitian yang lain adalah penelitian yang dilakukan oleh Sigied dkk. yang berjudul "Pengaruh durasi gesek, tekanan gesek dan tekanan tempa terhadap impact strength sambungan lasan gesek langsung pada baja karbon AISI 1045'”[3]. Respon yang diamati dalam penelitian ini adalah kekerasan sambungan, kekuatan impak dan struktur mikro. Hasil yang diperoleh menunjukkan bahwa sambungan lasan material AISI 1045 memiliki kekuatan impak semakin meningkat seiring dengan penambahan tekanan gesek dan tekanan tempa. Daerah sambungan menunjukkan nilai kekerasan paling tinggi dibanding dengan material induk, sedangkan struktur mikro pada material induk tidak terjadi banyak perubahan. Daerah HAZ yang dekat dengan weld metal memperlihatkan struktur mikro berupa ferrit dan pearlit dengan dominasi perlit kasar.

Penelitian serupa juga dilakukan oleh Shubhavardhan dkk., dengan judul "Friction welding to join dissimilar metal" [4]. Material yang disambung AISI 304 austenitic stainless steel dan AA6082 alumunium alloy. Parameter proses yang divariasikan adalah gaya gesek dan waktu gesek dengan respon yang diamati adalah kekuatan tarik dan kekerasan. Hasil dari penelitian ini menunjukkan bahwa kekuatan tarik meningkat seiring meningkatnya gaya gesek dan waktu gesek sampai nilai tertentu, saat mencapai titik optimum. Kekuatan tarik akan menurun dengan penambahan nilai gaya gesek dan waktu gesek lebih lanjut. Sedangkan kekerasan kedua material di sekitar daerah las lebih besar dari pada material induknya.

Berdasarkan hal-hal yang telah dijelaskan, penelitian tentang penentuan variasi variabel proses pada mesin las gesek perlu dilakukan untuk mengetahui fenomena yang dihasilkan pada variabel responnya. Pada penelitian ini akan dipelajari pengaruh kecepatan putar, gaya gesek dan waktu gesek pada proses penyambungan material SUH 3 dan SUH 35 terhadap struktur mikro dan laju korosi pada daerah sambungan.

\section{Material dan metodologi}

Dalam penelitian ini disambung dua buah baja yang berbeda jenis yaitu baja SUH 3 dan SUH 35 dengan mengunakan mesin las gesek tipe FW 10 NC. Penyambungan kedua material tersebut bertujuan untuk mendapatkan kekuatan pengelasan yang baik ditinjau dari hasil laju korosi dan sruktur mikro pada sambungan. 
Material benda kerja yang diamati pada proses las gesek adalah baja SUH 3 dan baja SUH 35. Baja SUH 3 dan SUH 35 berbentuk silindris dengan diameter $7.45 \mathrm{~mm}$ dipotong masing-masing dengan panjang $82 \mathrm{~mm}$ dan $209 \mathrm{~mm}$. Beberapa informasi awal tentang material tersebut didapat dari sertifikat material yaitu: Baja SUH 3 dengan nilai kekerasan 30-35 HRC dan tensile strength $93 \mathrm{kgf} / \mathrm{mm}^{2}$ (912 MPa) dan Baja SUH 35 dengan nilai kekerasan material 35-40 HRC dan tensile strength 88 kgf/mm² (863 MPa). Komposisi kimia kedua baja tersebut dapat dilihat pada Tabel 1.

Tabel 1. komposisi kimia material

\begin{tabular}{lllllllllll}
\hline \multirow{2}{*}{ Jenis Material } & \multicolumn{10}{c}{ Komposisi Kimia (\%) } \\
\cline { 2 - 11 } & $\mathrm{C}$ & $\mathrm{Si}$ & $\mathrm{Mn}$ & $\mathrm{P}$ & $\mathrm{S}$ & $\mathrm{Ni}$ & $\mathrm{Cr}$ & $\mathrm{N}$ & $\mathrm{Cu}$ & $\mathrm{Mo}$ \\
\hline SUH 3 & 0.42 & 1.89 & 0.28 & 0.25 & 0.009 & 0.27 & 10.14 & - & 0.12 & 0.71 \\
\hline SUH 35 & 0.56 & 0.20 & 8.52 & 0.026 & 0.001 & 3.71 & 21.13 & 0.42 & - & - \\
\hline
\end{tabular}

Sumber: Sertifikat material SUH 3 dan SUH 35

Pada proses las gesek, material baja SUH 3 diposisikan pada pencekam yang tidak berputar, sedangkan baja SUH 35 diletakkan pada pencekam yang berputar. Vareabel proses yang divariasikan dalam penelitian ini adalah kecepatan putar (v) sebesar (2500, 3000, 3500, 4000, 4500 dan 5000 rpm), gaya gesek F1 sebesar (6, 8, 10, 12, dan 14 kN) dan waktu gesek (T1) sebesar 0.6, 0.7, 0.8, 0.9 dan 1 detik. Variabel konstan adalah gaya tempa (F2) sebesar $16 \mathrm{kN}$ dan waktu tempa (T2) sebesar 1 detik.

Langkah selanjutnya adalah proses pengelasan yang diawali dengan mengatur parameter proses sesuai dengan variabel proses dan variabel konstan. Pengaturan parameter proses dilakukan melalui alat pengaturan yang sudah tersedia pada mesin. Besarnya nilai parameter proses aktual dikontrol oleh peralatan ukur yang terpasang pada mesin, kemudian nilainya diinformasikan melalui sebuah monitor yang terdapat pada mesin

Setelah dilakukan proses pengelasan gesek sesuai dengan variasi parameter yang ditetapkan, langkah selanjutnya adalah pengamatan struktur mikro dan pengukuran respon laju korosi. Struktur mikro yang diamati dengan mikroskop optik adalah struktur mikro daerah sambungan, material induk baja SUH 3 dan baja SUH 35. Benda kerja pada pengamatan struktur mikro disiapkan dengan menghaluskan permukaan material dengan menggunakan kertas gosok dengan tingkat kekasaran 220,400, 800, 1200, dan 2000, yang kemudian dilanjutkan dengan proses poles.Struktur mikro yang diamati dengan mikroskop optik adalah struktur mikro daerah sambungan, material induk baja SUH 3 dan baja SUH 35. Benda kerja pada pengamatan struktur mikro disiapkan dengan menghaluskan permukaan material dengan menggunakan kertas gosok dengan tingkat kekasaran 220, 400, 800, 1200, dan 2000, yang kemudian dilanjutkan dengan proses poles.

Larutan etsa yang digunakan agar struktur mikro dapat diamati adalah campuran dari $20 \mathrm{ml}$ hydrochloric acid (HCl) $36 \%$, 4 gr copper (II) sulfate penthahydrate $\left(\mathrm{CuSO}_{4} 5 \mathrm{H}_{2} \mathrm{O}\right) 99 \%$, dan $20 \mathrm{ml}$ aquades $\left(\mathrm{H}_{2} \mathrm{O}\right)$ untuk mengamati struktur mikro baja tahan panas [5]. Pengamatan struktur mikro dilakukan dengan menggunakan mikroskop optik. Pengamatan menggunakan scanning electron microscope untuk mengamati struktur mikro permukaan, dan menganalisa komposisi unsur kimia didaerah sambungan baja SUH 3 dan SUH 35 setelah dilakukan proses pengelasan.

Pengujian laju korosi pada penelitian ini dilakukan pada sambungan antar muka. Pengujian dilakukan dengan menggunakan potensiostat untuk mendapatkan data kerapatan arus $\left(\mathrm{I}_{c o r}\right)$ dan potensial $\left(\mathrm{E}_{c o r}\right)$. Data tersebut merupakan data yang dibutuhkan untuk menghitung laju korosi. Data awal yang harus diketahui adalah densitas material, berat equivalent, luasan area yang akan diuji dan lama waktu pengujian. Material yang diuji sebagai elektoda kerja disambung 
dengan kawat tembaga kemudian dimounting dengan menggunakan resin supaya pada saat pengujian hanya permukaan material yang bereaksi. Setelah dimounting kemudian permukaan dihaluskan dengan kertas gosok dengan tingkat kekasaran 220, 400, 800, 1200, dan 2000. Gambar 2 merupakan specimen untuk pengujian laju korosi. Pengujian laju korosi dilakukan dengan menggunakan sel tiga elektroda yang dilengkapi dengan perangkat software NOVA 1.8.

\section{Hasil dan pembahasan}

\subsection{Pengamatan mikroskop optik}

Pengamatan struktur mikro dilakukan didaerah material induk, daerah deformasi plastis dan daerah sambungan. Hasil pengamatan menunjukkan bahwa baja SUH 35 memiliki stuktur mikro dengan butir yang besar dibandingkan dengan butir pada baja SUH 3.

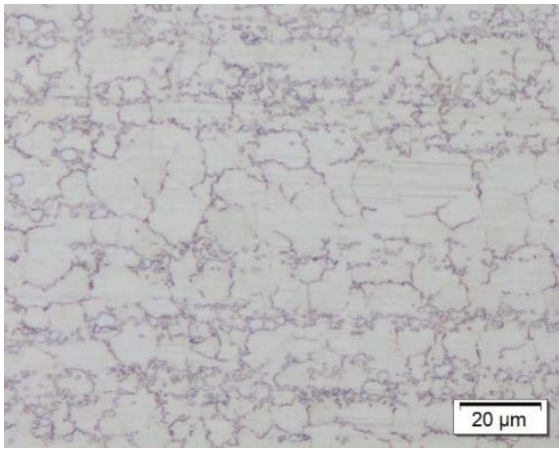

(a)

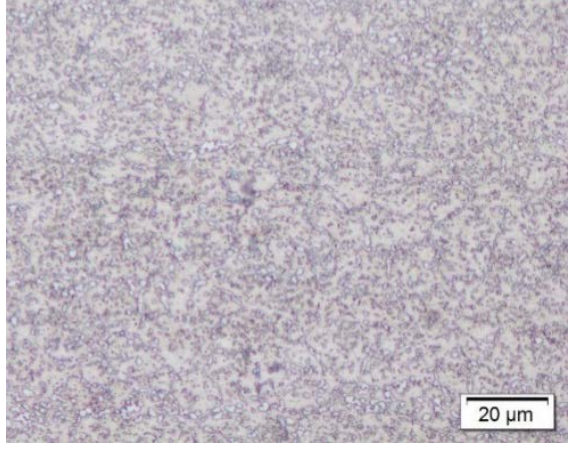

(b)

Gambar 1. Strukrur Mikro Material Induk (a) SUH 35, (b) SUH 3

Gambar 1 (a) merupakan struktur mikro baja SUH 35 sebelum proses terjadinya pengelasan, sedangkan Gambar 1 (b) merupakan struktur mikro baja SUH 3 sebelum proses pengelasan. Kedua gambar tersebut menunjukkan bahwa material SUH 3 dan SUH 35 merupakan material yang berbeda dari segi pola butiran yang terbentuk. Material SUH 3 memiliki butiran yang lebih kecil dibandingkan dengan material SUH 35, proses pembentukan baterial SUH 3 dengan Hot Rolled dan Annealed. Struktur Mikro hasil dari pengelasan dengan menggunakan las gesek ditunjukkan pada Gambar 2 (a) dan (b).

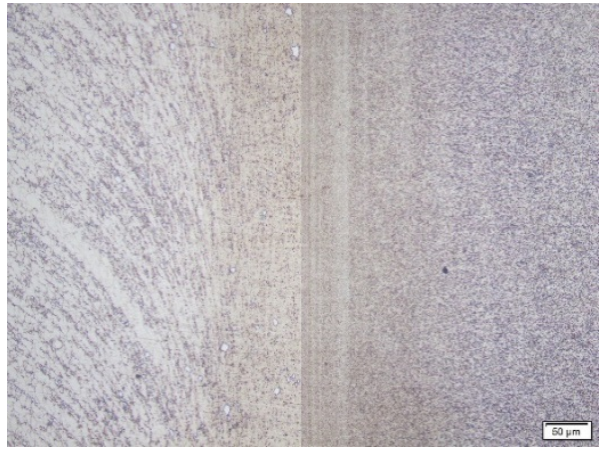

(a)

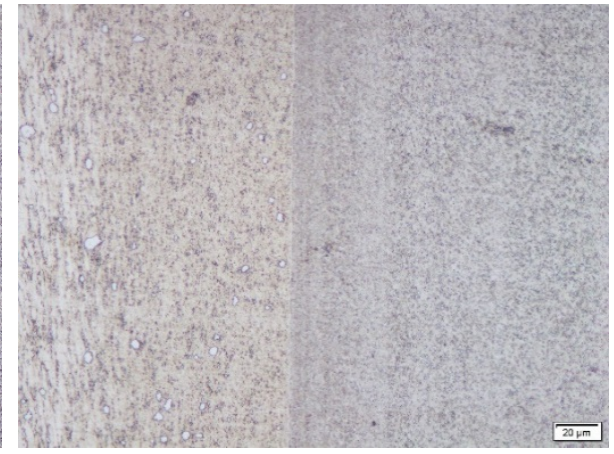

(b)

Gambar 2. Struktur Mikro pada Sambungan (a) SUH 3 dan (b) SUH 35.

Daerah sekitar sambungan memiliki struktur mikro dengan butir yang terdeformasi plastis. Daerah sambungan dan deformasi plastis merupakan bagian yang terpengaruh oleh panas akibat gesekan ketika proses pengelasan terjadi. Butiran yang terbentuk pada daerah terdeformasi plastis cenderung membentuk butiran yang lebih kecil dan pipih dibandingkan 
dengan butiran pada material yang tidak terdeformasi atau material induknya. Menurut shiva shankar dalam penelitiannya menyatakan bahwa struktur mikro pada HAZ dan WZ (weld zone) diamati dan didapatkan bahwa hasil sambungan tidak terdapat cacat seperti blow holes, carck, voids, impurities, dan ukuran butiran kecil ke arah WZ [6].

Baja SUH 35 pada saat proses pengelasan berputar dengan kecepatan putar tertentu sehingga butiran yang terbentuk pada material SUH 35 cenderung menjauhi titik pusat material. Butiran tersebut mengalir dengan pola menjauhi titik pusat sambungan diakibatkan oleh gaya sentrifugal akibat dari pengaruh kecepatan putar.

\subsection{Pengamatan Scanning Elektron Microscopy-EDX}

Pengamatan SEM-EDX material hasil pengelasan bertujuan untuk mengetahui sebaran unsur logam di antaranya Cr, $\mathrm{Mn}, \mathrm{Fe}, \mathrm{Ni}, \mathrm{Cu}$ dan Mo. Gambar 3 menunjukkan contoh gambar katakterisasi unsur logam pada pengujian dengan menggunakan SEM-EDX.

Gambar 3. Karakterisasi unsur kromium

Hasil dari pengujian karakterisasi atom menunjukkan bahwa unsur logam $\mathrm{Cr}$ paling banyak berada pada daerah material SUH 35 dibandingkan dengan material SUH 3. Pada pengujian karakterisasi dengan menggunakan SEM-EDX unsur-unsur logam dapat dikarakterisasi dengan warna merah untuk kromium.

Unsur logam pada daerah sambungan menghasilkan persentase unsur yang berbeda dengan logam induknya. Hasil persentase komposisi unsur logam pada daerah sambungan ditunjukkan pada Gambar 4 dan ditunjukkan pada Tabel 2.

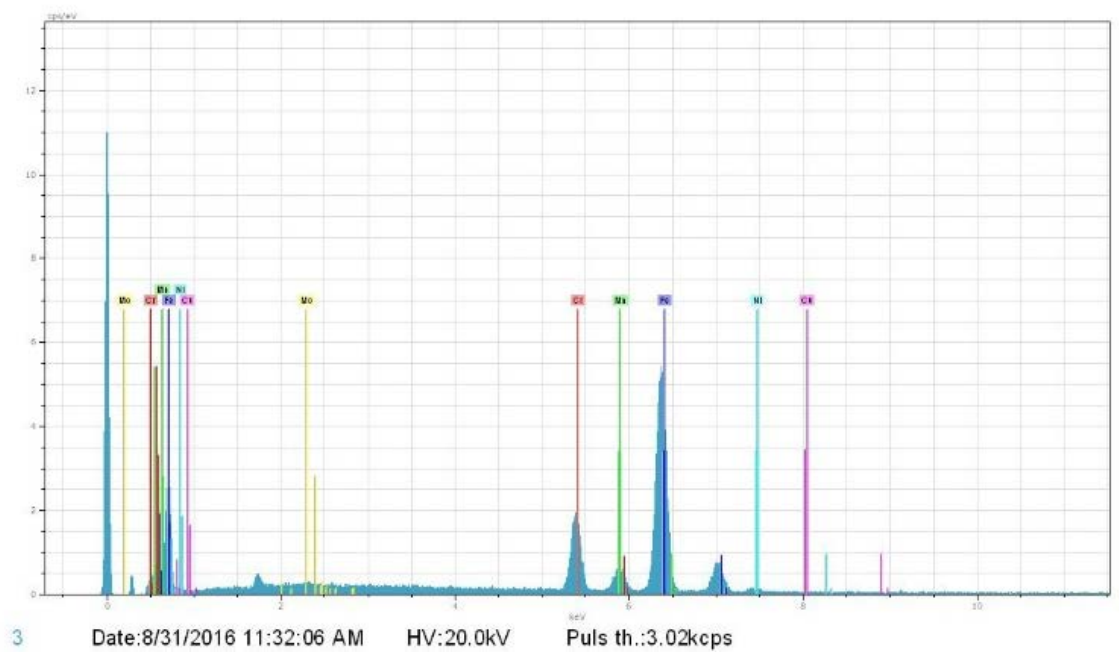

Gambar 4. Persentase unsur logam di daerah sambungan pada kecepatan putar 2500 rpm. 
Tabel 2. Persentase unsur logam pada sambungan kecepatan putar 2500 rpm

\begin{tabular}{ccccccc}
\hline El & AN & Series & $\begin{array}{c}\text { Unn. C } \\
\text { (wt.\%) }\end{array}$ & $\begin{array}{c}\text { Norm. C } \\
\text { (wt.\%) }\end{array}$ & $\begin{array}{c}\text { Atom. C } \\
\text { (at.\%) }\end{array}$ & $\begin{array}{c}\text { Error } \\
\text { (\%) }\end{array}$ \\
\hline $\mathrm{Cr}$ & 24 & $\mathrm{~K}$ & 13,25 & 14,00 & 14,99 & 0,4 \\
$\mathrm{Mn}$ & 25 & $\mathrm{~K}$ & 4,29 & 4,54 & 4,60 & 0,2 \\
$\mathrm{Fe}$ & 26 & $\mathrm{~K}$ & 72,99 & 77,12 & 76,89 & 2,0 \\
$\mathrm{Ni}$ & 28 & $\mathrm{~K}$ & 1,89 & 2,00 & 1,90 & 0,1 \\
$\mathrm{Cu}$ & 29 & $\mathrm{~K}$ & 0,87 & 0,92 & 0,80 & 0,1 \\
$\mathrm{Mo}$ & 42 & $\mathrm{~L}$ & 1,35 & 1,43 & 0,83 & 0,1 \\
\hline
\end{tabular}

Pengujian dengan menggunakan SEM-EDX bertujuan untuk mengetahui dan mendapatkan data persentase unsur logam pada daerah sambungan, yang dimungkinkan di daerah tersebut terbentuk komposisi material baru diakibatkan oleh proses pengelasan baja SUH 3 dengan baja SUH 35. Pada kecepatan putar 2500 rpm didapatkan unsur logam Cr 14,99 at.\%, Mn 4,60 at.\%, Fe 76,89 at.\%, Ni 1,90 at.\%, Cu 0,80 at.\%, dan Mo 0,83 at.\%.

Hasil persentase unsur logam pada pengelasan dengan menggunakan kecepatan putar 2500 rpm diduga juga telah terjadi difusi atomik baik secara interstisi ataupun subsitusi. Mekanisme difusi tersebut yang akan menghasilkan persentase unsur yang tidak sama dengan persentase dengan logam induknya. Fenomena difusi pada atom Cr juga kemungkianan baja SUH 35 mengalirkan atom Cr pada daerah yang mmemiliki Cr lebih sedikit pada baja SUH 3. Hasil pengamatan SEM-EDX yang ditunjukkan pada Tabel 3 pada pengambilan titik material induk SUH 35 jarak 1 mm dari sambungan menunjukkan bahwa atom Cr sudah mengalami penurunan persentase, dari yang awalnya Cr pada material induk sebesar 21,13\% menjadi 20,87 at.\%.

Tabel 3. Persentase unsur di material induk SUH 35 jarak 1 mm dari sambungan kecepatan putar 2500 rpm

\begin{tabular}{ccccccc}
\hline El & AN & Series & $\begin{array}{c}\text { Unn. C } \\
\text { (wt.\%) }\end{array}$ & $\begin{array}{c}\text { Norm. C } \\
\text { (wt.\%) }\end{array}$ & $\begin{array}{c}\text { Atom. C } \\
\text { (at.\%) }\end{array}$ & $\begin{array}{c}\text { Error } \\
\text { (\%) }\end{array}$ \\
\hline $\mathrm{Cr}$ & 24 & $\mathrm{~K}$ & 18,44 & 19,59 & 20,87 & 0,6 \\
$\mathrm{Mn}$ & 25 & $\mathrm{~K}$ & 8,73 & 9,27 & 9,35 & 0,4 \\
$\mathrm{Fe}$ & 26 & $\mathrm{~K}$ & 61,33 & 65,10 & 64,62 & 1,7 \\
$\mathrm{Ni}$ & 28 & $\mathrm{~K}$ & 3,56 & 3,78 & 3,57 & 0,2 \\
$\mathrm{Cu}$ & 29 & $\mathrm{~K}$ & 0,87 & 0,93 & 0,81 & 0,1 \\
$\mathrm{Mo}$ & 42 & $\mathrm{~L}$ & 1,28 & 1,36 & 0,79 & 0,1 \\
\hline & Total & & 94,21 & 100,00 & 100.00 & - \\
\hline
\end{tabular}

Material SUH 3 dan SUH 35 yang telah dilas dengan menggunakan las gesek menggunakan kecepatan putar 4500 rpm juga diamati pada daerah sambungan. Tujuan pengamatan yaitu untuk melihat sebaran unsur logam di antaranya Cr, Mn, Fe, Ni, Cu dan Mo. Unsur logam di daerah sambungan menghasilkan persentase unsur yang berbeda dengan logam induknya. Hasil persentase unsur logam ditunjukkan pada Gambar 5 dan ditunjukkan pada Tabel 4.

Gambar 5 menunjukkan hasil SEM-EDX dengan menampilkan persentase unsur yang berada pada daerah sambungan. Pada kecepatan putar 4500 rpm didapatkan unsur Cr 15,82\%, Mn 5,01\%, Fe 75,47\%, Ni 1,82\%, Cu 0,99\%, dan Mo 0,89\%. Pada penambahan kecepatan putar unsur logam yang mengalami peningkatan presentase pada daerah sambungan adalah $\mathrm{Cr}$, Mn dan Cu. Unsur logam yang mengalami penurunan persentase adalah Fe dan Ni sedangkan persentase Mo 
cenderung kenaikannya kecil sebesar $0.06 \%$. Kenaikan unsur logam $\mathrm{Cr}$ dan Mn dikarenakan pengaruh kecepatan putar diduga akan menghasilkan perbedaan laju korosi pada kecepatan putar rendah dengan kecepatan putar tinggi.

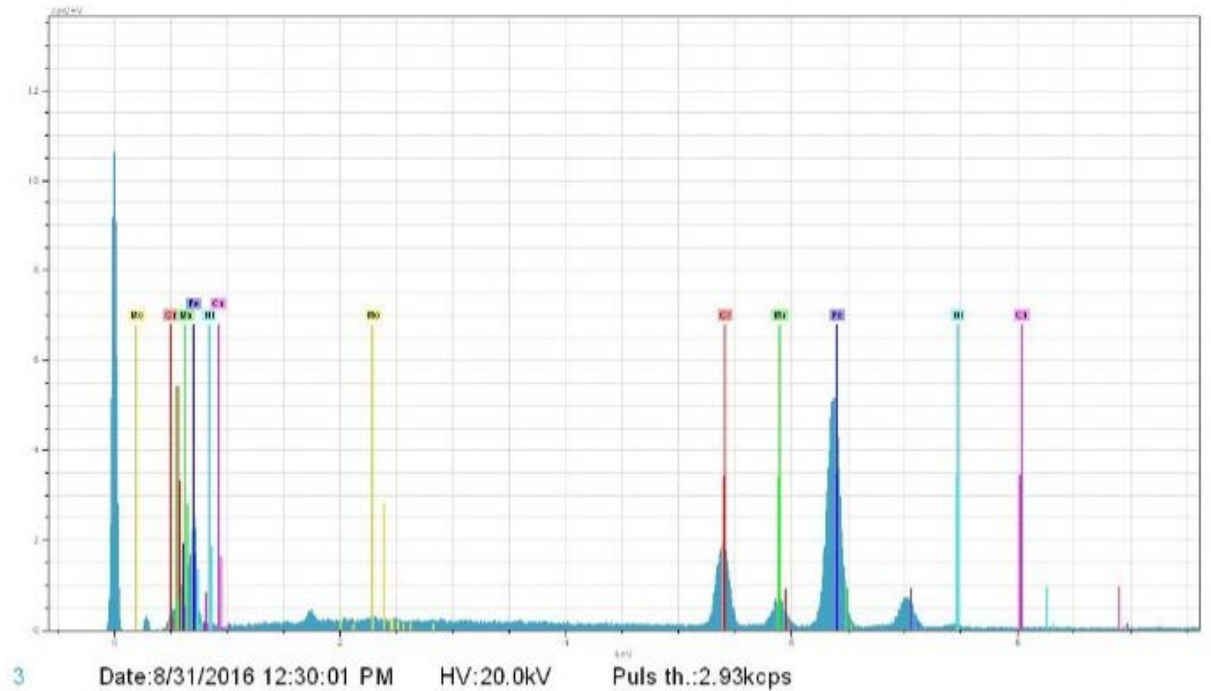

Gambar 5. Persentase Unsur Logam di Daerah Sambungan Pada Kecepatan Putar 4500 rpm

Tabel 4. Persentase unsur logam pada sambungan kecepatan putar $4500 \mathrm{rpm}$

\begin{tabular}{ccccccc}
\hline El & AN & Series & $\begin{array}{c}\text { Unn. C } \\
\text { (wt.\%) }\end{array}$ & $\begin{array}{c}\text { Norm. C } \\
\text { (wt.\%) }\end{array}$ & $\begin{array}{c}\text { Atom. C } \\
\text { (at.\%) }\end{array}$ & $\begin{array}{c}\text { Error } \\
\text { (\%) }\end{array}$ \\
\hline $\mathrm{Cr}$ & 24 & $\mathrm{~K}$ & 14,07 & 14,77 & 15,82 & 0,5 \\
$\mathrm{Mn}$ & 25 & $\mathrm{~K}$ & 4,71 & 4,94 & 5,01 & 0,3 \\
$\mathrm{Fe}$ & 26 & $\mathrm{~K}$ & 72,11 & 75,71 & 75,47 & 2,0 \\
$\mathrm{Ni}$ & 28 & $\mathrm{~K}$ & 1,83 & 1,92 & 1,82 & 0,1 \\
$\mathrm{Cu}$ & 29 & $\mathrm{~K}$ & 1,08 & 1,13 & 0,99 & 0,1 \\
$\mathrm{Mo}$ & 42 & $\mathrm{~L}$ & 1,46 & 1,53 & 0,89 & 0,1 \\
\hline
\end{tabular}

Semakin tinggi kecepatan putar pada las gesek dimungkinkan akan menghasilkan temperatur yang lebih tinggi dibandingkan kecepatan putar rendah, sehingga makin tingginya temperatur tersebut akan menyebabkan difusifitas makin tinggi pula, karena atom-atom memiliki energi termal yang lebih tinggi dan dengan demikian probabilitas untuk melampaui hambatan antar atom juga lebih besar [7]. Jika atom-atom dapat mengalami difusi tanpa hambatan pada kecepatan putar tinggi dimungkinkan akan menghasilkan ikatan antar muka antara baja SUH 3 dan SUH 35 lebih baik ditinjau dari sifat mekanik hasil sambungan. Sesuai dengan penelitian yang dilakukakan oleh shankar dkk yang menyimpulkan bahwa kekuatan sambungan meningkat saat P1 meningkat dan kecepatan putar tinggi [8].

\subsection{Pengujian laju korosi}

Laju korosi baja SUH 3 dan SUH 35 sangatlah dipengaruhi dari unsur - unsur logam yang berada pada baja paduan. Baja SUH 3 dan SUH 35 sama-sama memiliki kandungan unsur Cr yang dapat memproteksi terjadinya korosi pada Fe. Akan tetapi persentase Cr dari baja SUH 3 dan SUH sangat berbeda. Perbedaan hasil laju korosi tersebut dipengaruhi oleh perbedaan persentase unsur Cr pada baja SUH 3 sebesar 10.14\% sedangkan unsur Cr pada baja SUH 35 sebesar 
21.13\%. Perbedaan kandungan Cr pada kedua baja tersebut juga mempengaruhi hasil pengujian laju korosi baja SUH 3 dan SUH 35. Grafik hasil Pengujian laju korosi sebagai fungsi kecepatan putar ditunjukkan pada Gambar 6. Peningkatan kecepatan putar menyebabkan laju korosi semakin menurun. Kecepatan putar maksimal pada 4500 rpm menghasilkan laju korosi sebesar $0.051 \mathrm{~mm} / \mathrm{tahun}$. Pada kecepatan putar 4500 unsur logam $\mathrm{Cr}$ cenderung mengalami peningkatan (Tabel 4) dibandingkan pada kecepatan putar rendah (Tabel 2) sehingga berdampak pada hasil pengujian laju korosi. Peningkatan Cr pada putaran spindel 4500 rpm diduga mampu menghambat laju korosi dari Fe, sehingga Fe akan terproteksi oleh Cr.

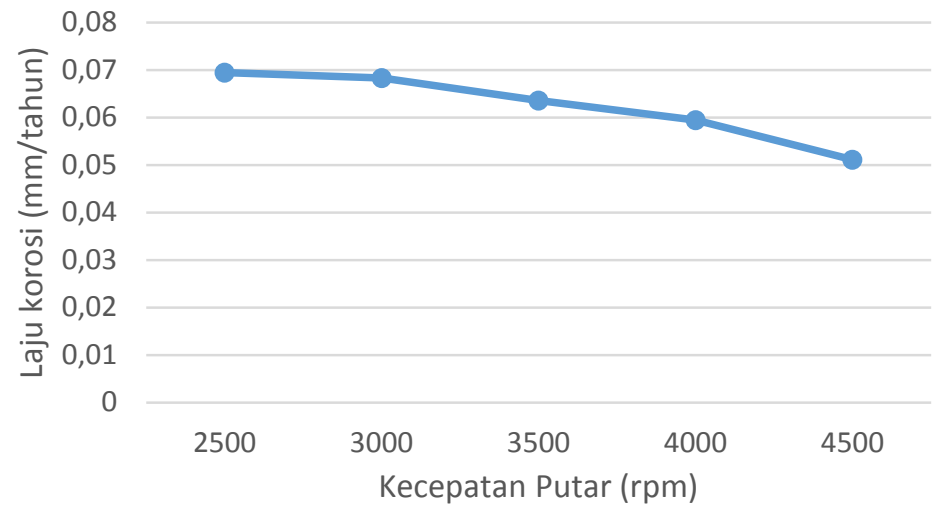

Gambar 6. Grafik Laju Korosi Sebagai Fungsi Kecepatan Putar

S.T Selvamani dalam tulisannya menyimpulkan bahwa pada kecepatan putar rendah kontak antara permukaan yang dilas kurang kuat sehingga menghasilkan sambungan las kurang baik. Dilihat dari struktur butiran yang terbentuk didaerah sambungan merupakan butiran kasar [9]. Hal tersebut dimungkinkan ada hubungan antara butiran kasar yang dihasilkan oleh kecepatan putar rendah, dengan hasil uji laju korosi yang cenderung lebih tinggi.

Gambar 7 menunjukkan grafik hasil pengujian laju korosi sebagai fungsi gaya gesek. Laju korosi paling rendah didapatkan pada gaya gesek sebesar $10 \mathrm{kN}$, sehingga kemungkinan sambungan yang menghasilkan lajukorosi paling baik berada pada kondisi gaya tekan sebesar $10 \mathrm{kN}$. Sambungan lasan dengan nilai laju korosi paling rendah berarti sambungan tersebut memiliki ketahanan terhadap korosi paling tinggi. Hal tersebut dimungkinkan pada kondisi gayatekan $10 \mathrm{kN}$ memiliki unsur Cr yang lebih banyak daripada saat gaya gesek yang lain.

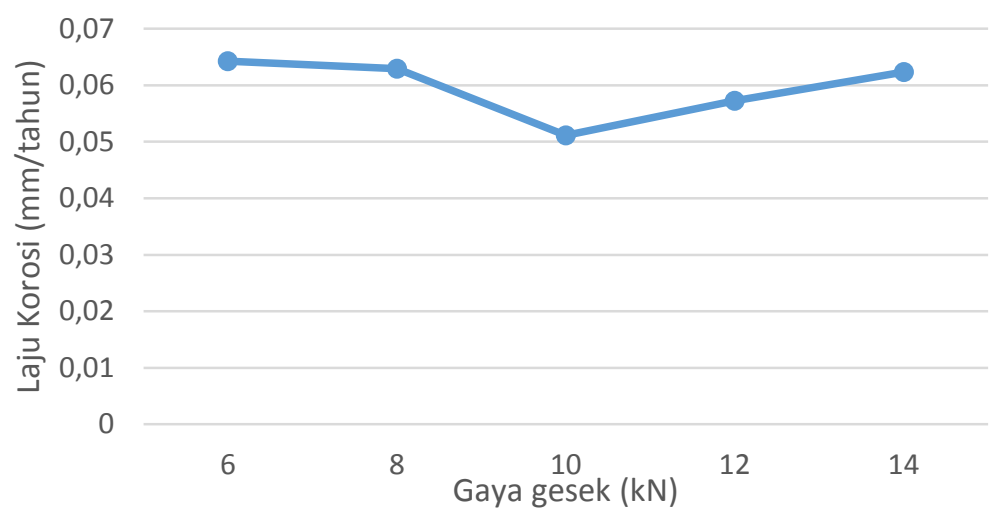

Gambar 7. Grafik Laju Korosi Fungsi Gaya Gesek

Gambar 8 menunjukan grafik hasil pengujian laju korosi sebagai fungsi penambahan waktu tekan dari 0.6 detik sampai dengan 1 detik. Penambahanwaktugesekselama 1 detik menunjukkan nilai laju korosi paling rendah yaitu sebesar $0.051 \mathrm{~mm} / \mathrm{tahun}$. Waktu gesek 1 detik menghasilkan laju korosi yang lebih rendah. 


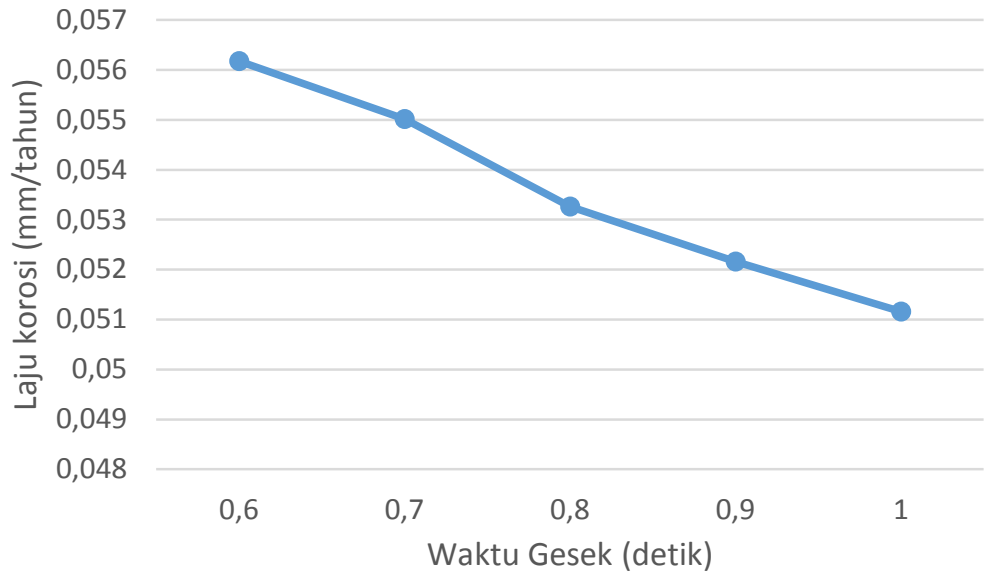

Gambar 8. Grafik Pengujian Laju Korosi Fungsi Waktu Gesek

Suhu atau temperatur yang dihasilkan pada proses pengelasan dengan menggunakan las gesek kemungkinan dipengaruhi oleh kecepatan putar dan waktu gesek. Semakin tinggi kecepatan putar dan semakin lama waktu gesek akan menghasilkan suhu yang tinggi. Pada saat suhu yang dihasilkan semakin tinggi menyebabkan difusivitas makin tinggi pula, karena atom-atom memiliki energi termal yang lebih tinggi dan dengan demikian atom-atom dapat mengalami vibrasi tanpa hambatan. Atom $\mathrm{Cr}$ cenderung mengalami peningkatan pada suhu tinggi di daerah sambungan sehingga dapat menurunkan laju korosi pada sambungan. Hasil penelitian yang dilakukan oleh R. Sathish yang dipublikasikan didalam International Journal of Electrochemichal Science menyimpulkan bahwa laju korosi didaerah sambungan menurun dibandingkan dengan laju korosi pada material induk [10].

\section{Kesimpulan}

Berdasarkan hasil penelitian dan pembahasan yang telah dilakukan, maka dapat disimpulkan bahwa hasil pengamatan struktur mikro menunjukkan bahwa pada pengelasan baja SUH 3 dan SUH 35 terjadi perubahan struktur mikro dan perbedaan orientasi kristal pada daerah sambungan. Pengamatan dengan menggunakan scanning elektron microscopy EDX pada hasil pengelasan dengan kecepatan putar 2500 rpm dan 4500 rpm menunjukkan perubahan komposisi kimia pada sambungan. Kandungan $\mathrm{Cr}$ meningkat seiring dengan penambahan kecepatan putar dari 2500 rpm hingga 4500 rpm. Prosentase Cr pada kecepatan putar 2500 rpm sebesar 14.99\%, dan menjadi 15.82\% pada kecepatan putar 4500 rpm. Pengelasan pada kecepatan putar $4500 \mathrm{rpm}$, gaya gesek $10 \mathrm{kN}$ dan waktu gesek 1 detik menurunkan laju korosi sampai $0.051 \mathrm{~mm} / \mathrm{tahun}$.

\section{Daftar Pustaka}

[1] ASM Handbook Internasional, (1993), Welding Brazing and Soldering, Vol. 6, AS.

[2] Subhavardhan, R.N, dan Surendran, S, (2012) "Friction welding to joining dissimilar metals", International journal of emerging technology and advance engineering, Volume 2 ISSN 2250-2459.

[3] Sigied prasetiyono dan Ir Hari subiyanto M.Sc. (2012), "Pengaruh durasi gesek, tekanan gesek, dan tekanan tempa terhadap impact strength sambungan lasan gesek langsung pada baja karbon AISI 1045”. Jurnal sains dan seni pomits vol.1, No. 1, (2012) 1-5.

[4] Kirik, I. dan Ozdemir, N. (2014), 'Effect of Process Parameters on The Microstructure And Mechanical Properties Of Friction-Welded Joints Of AISI 1040/AISI 304L Steels”, Journal Material and technology 49 (2015) 5, 825-832. 
[5] ASM Handbook Internasional, (1993), Metallography and microstructures, Vol 6 AS.

[6] P. Shiva Shankar, L. Suresh Kumar dan N. Ravinder Reddy, (2013) "Experimental Investigation and Statistical Analisys of The Friction Welding Parameters For The Copper Alloy - CU Zn28 Using Taguchi Method”, International Journal of Research in Engineering and Technology, eISSN: 2319-1163 | pISSN: 2321-7308.

[7] Callister, W. D. \& Rethwisch, D.G. (2007), Materials science and engineering: an introduction (Vol. 7, pp. 665715), New York: Wiley.

[8] P. Shiva Shankar, L. Suresh Kumar dan N. Ravinder Reddy, (2013), "Experimental Investigation and Statistical Analisys of The Friction Welding Parameters For The Copper Alloy - CU Zn28 Using Taguchi Method” IJRET: International Journal of Research in Engineering and Technology eISSN: 2319-1163 | pISSN: 2321-7308.

[9] S.T. Selvamani, K. Palanikumar, K. Umanath, D. Jayaperumal, (2014), "Analysis of Friction welding parameterson the Mechanical Metallurgical and Chemical properties of AISI 1035 steel joints”. Journal Material \& Design ISSN 0261-3069.

[10] R. Sathish, V. Seshagiri Rao, (2014), “Corrosion Studies on Friction Welded Dissimilar Aluminum Alloys of AA7075-T6 and AA6061 -T6”. International Journal of Electrochemichal Science 4104-4113. 